\title{
Examining the Effect of Transformational Leadership Method on Organizational Learning According to Organizational Forgetting Moderator in Astara Custom Organization
}

\author{
Hamid Taboli \\ Associate Professor and faculty member, PNU \\ Email: htaboli@yahoo.com
}

Mohammad Reza Rezaeian

PhD student of Public Administration - Human Resource Management, Islamic Azad University, Kerman Email:mr.rezaiian@gmail.com

\section{Doi:10.5901/mjss.2016.v7n4s1p160}

\section{Abstract}

In today's competitive and complex environment, organizations need to create increasing learning ability. Among the factors that affect learning abilities in organizations is transformational leadership method. This research is done to test how transformational leadership method effects organizational learning. Organizational intentional and accidental forgetting have been selected as moderating variable. Based on these variables, a questionnaire include 64 questions was designed and it's standard through factor analysis was confirmed and stability of questionnaires of transformational leadership method and organizational learning and organizational forgetting are respectively $(0.76,0.78,0.89)$. Statistical society of researcher is 138 employees of Astara's custom organization which according to limited sampling fomula,103 employees were selected. Researcher's data were collected through questionnaires and data analysis was done through regression test. Research results show that transformational leadership method has a significant effect on organizational learning and all it's dimensions. Here, intentional organizational forgetting could moderate the effect of transformational leadership method on organizational learning. Eventually, practical suggestions in such context was presented to senior managers.

Keywords: transformational leadership method, organizational learning, organization forgetting, (intentional, accidental) and Astara custom organization.

\section{Introduction}

According to the researches which done in recent years in the world and importance of transformational leadership as a successful leadership in today's organizations and it's positive effect in various fields and also necessity of learning evaluation as a important factor of organizations effectiveness, if an organization wants to be learned in such a situation and compatible itself with increasing differences in these years, should make development of transformational leadership as it's priority and try to improve and expand them in order to promote organizational learning level. Therefore, according to research importance and analyzing the previous researches, this research is looking for analyzing the effect of transformational leadership on organizational learning as a necessity for stability of organizations through the forgetting moderating role. Eventually it is hoped to results of following research could provide needed data and knowledge in the field of transformational leadership development as a factor in order to improve organizational learning and apply organizational forgetting to the managers. In the following, statement of issue importance and necessity, goals, assumptions and words defining will be discussed.

\section{Main text}

\subsection{Statment of issue}

A new concept which due to becoming the organizations complex, and due to great and unpredictable of world has attracted much attention, is the concept of learner organization. Organizations which people there do not resistance against varieties unlike the traditional organizations, but always trying to be changing and make the environment compatible with themselves, and one of the important features of this organizations is learning. A type of learning in which 
behaviors and attitudes of people is changed and people learn how to think in new way and how to learn together and how to close up their ideas and mental imaginations together.

Organizational learning means learning of people and groups in the organization. Tesnong believes that 2 phrases of organizational learning and learner organization sometimes are used wrong interchangeably. He knows the organizational learning as a concept that is used to describe for certain types of activities which done in the organization while the learner organization implies to certain type of organization. In other words we should say that learner organization is the result of organization learning. Effective leadership is one of the main factors of improve and development and gain the competitive advantage in the in organization and we could by efficient management to provide the appropriate field in order to stable development and correct and optimized guidance of organizations labor and also preventing of organizational energy and property. The subject recently has attracted the attention of most researchers is that how behave with employees and lead them in the desired direction through reward and punishment.

Here it is obvious that whatever the organization be dynamic, necessity of organizational learning is more. Organizational learning in organizations as a business institution which has a immediate and close and continuous relation with clients, has a considerable importance. Increasing improve of different organizations requires to provide various services to clients in order to resting in the business world. In addition, these services must be uptrend. It means that newer services provide continuously. Thus, employees should be learned about new innovative proceedings which this itself shows the necessity of attention to organizational learning as a customer oriented institution.

According to what has be mentioned and the importance of organizational learning and the effect of the style of leadership method on organizational learning, the researcher is going to examine how transformational leadership method effects on organizational learning. Here, according to what has be mentioned, organizational forgetting variable has been selected as the moderator variable.

\subsection{A discussion about key words}

\subsubsection{Transformational leadership}

Boss (1997) defines the transformational leadership as a process of giving an assurance to organizational goals and improve the followers in order to achieve those goals (Burke and Collins, 2001, 244). Dimensions of transformational leadership include idealized influence, inspirational motivation, intellectual stimulation and individual consideration (Spector and others, 2004, 18 and 19) which measure through Beth and Avllio's questionnaires (2000).

\subsubsection{Organizational learning}

Organizational learning is the dynamic process of creation and acquisition of knowledge, publish and share the knowledge and use it (Morales and partners, 2006, 299-319). Dimensions of the organizational learning of Senge's (1990) perspective: Common outlook, group learning, intellectual models, systematic and development of employees' qualification, which measure through Nife's (2000) questionnaire.

\subsubsection{Organizational forgetting}

Organizational forgetting unlike the organizational learning that shares the organizational knowledge causes to losing it. From the perspective of Dee Hallen and Philips (2004), organizational forgetting is voluntary or involuntary losing of organizational knowledge could leads to change the organizational capabilities. Organizational forgetting is the result of actions done in and out of organization that an organization lose some of its knowledge during it. Dimensions of organizational forgetting are: intentional and accidental organization forgetting which is measured through Helen and Philips (2004) questionnaire.

A. Intentional organizational forgetting: the set of actions, which an organization do to facilitate the forgetting of unnecessary data, and prevent losing useful data.

B. Accidental forgetting: accidental organizational forgetting (non-intentional) generally is related to losing the valuable knowledge, which can lead to decrease the competitiveness and loss of the organization. 


\subsection{Research theoretical literature}

Table 1: Research internal history

\begin{tabular}{|l|l|l|}
\hline REASEARCHER & YEAR & RESULTS \\
\hline $\begin{array}{l}\text { Khalifa Sultani and } \\
\text { Hosseini }\end{array}$ & 2012 & $\begin{array}{l}\text { Transformational leadership and its entire dimensions have direct and considerable effect on development } \\
\text { of learner organization and transformational leadership could provide an appropriate social background for } \\
\text { developing the organizational learning. }\end{array}$ \\
\hline Mir Kamali et al & 2011 & $\begin{array}{l}\text { There are positive and meaningful relation between the components of transformational leadership and the } \\
\text { components of organizational learning. Eventually, idealized influence (behavior) is the most important } \\
\text { predictor of organizational learning as one of the evolutionary leadership dimension. }\end{array}$ \\
\hline Amir Kabiri & 2014 & $\begin{array}{l}\text { Transformational leadership has significant influence on learning and organizational innovation and } \\
\text { innovation and organizational learning also have significant influence on organizational operation that } \\
\text { accordingly the effect of transformational leadership on employees operation is confirmed by these two } \\
\text { components. }\end{array}$ \\
\hline Azizi Nejad & 2014 & $\begin{array}{l}\text { Result achieve from model with good qualification show that leadership method (changing and } \\
\text { transformational) have a direct and meaningful effect on intentional organizational forgetting. Leadership } \\
\text { method (changing and transformational) has a direct and positive effect on organizational operation and } \\
\text { also leadership method through intentional organizational forgetting has an indirect effect on organization. }\end{array}$ \\
\hline Asgari & 2014 & $\begin{array}{l}\text { Transformational leadership and all its dimensions have direct and considerable effect on developing } \\
\text { learner organization and transformational leadership can provide an appropriate social background to } \\
\text { develop the organizational learning. }\end{array}$ \\
\hline
\end{tabular}

Table 2: Research internal background

\begin{tabular}{|l|l|l|}
\hline REASEARCHER & YEAR & RESULTS \\
\hline Ash & 1997 & $\begin{array}{l}\text { Transformational leaders' behavior and their actions usually effect the individual, group, and organizational } \\
\text { learning. Therefore, organizations through educational programs should learn their leaders that they have } \\
\text { important role in organizational learning, systematic thinking and creating a learner organization. }\end{array}$ \\
\hline Maverina & 2005 & $\begin{array}{l}\text { The learning needs to changing and the changing needs to transformational leadership. He believes that the } \\
\text { transformational leadership is the most basic dimension of changing and improve the changing process. }\end{array}$ \\
\hline Trotmen et al & 2005 & $\begin{array}{l}\text { Effective learning predict the transformational leadership satisfactory by experience in addition repetitious use } \\
\text { of thinking and practical learning strategies have positive and satisfactory relationship with transformational } \\
\text { leadership.. }\end{array}$ \\
\hline Newbury & 2008 & $\begin{array}{l}\text { During the any changing whether transformational or evolutionary human resources are considered the main } \\
\text { elements and the leadership is the main tool to improve the organizations and change them toward efficiency } \\
\text { and effectiveness. }\end{array}$ \\
\hline Kuria et al & 2008 & $\begin{array}{l}\text { Leadership especially transformational leadership has a positive effect on organization learning through } \\
\text { innovation. Transformational leadership and organizational learning cause to creativity and transformational } \\
\text { leadership emphasis more than the traditional leadership on group decision-making, group goals and } \\
\text { qualification of people. In addition, the transformational leadership has a potential power to help the } \\
\text { organization members in order to create and using knowledge and one of the outputs of this method of } \\
\text { leadership is to catch ideas to improve the organization learning. }\end{array}$ \\
\hline
\end{tabular}

\subsection{Research hypothesis}

\subsubsection{Main hypothesis 1}

Transformational leadership method influences the organization learning.

\subsubsection{Subsidiary hypothesis}

- Transformational leadership method influences the common outlook.

- Transformational leadership method influences the group learning.

- Transformational leadership methods influences the intellectual models.

- Transformational leadership method influences the systematic thinking.

- Transformational leadership method influences the development of employees' qualification. 


\subsubsection{Main hypothesis 2}

Organization forgetting moderate the influence of transformational leadership method on the organizational learning

\subsubsection{1 subsidiary hypothesis}

Intentional organizational forgetting moderate the influence of transformational leadership method on the organizational learning.

Accidental organizational forgetting moderate the influence of transformational leadership method on the organizational learning.

\subsection{Research conceptual method}

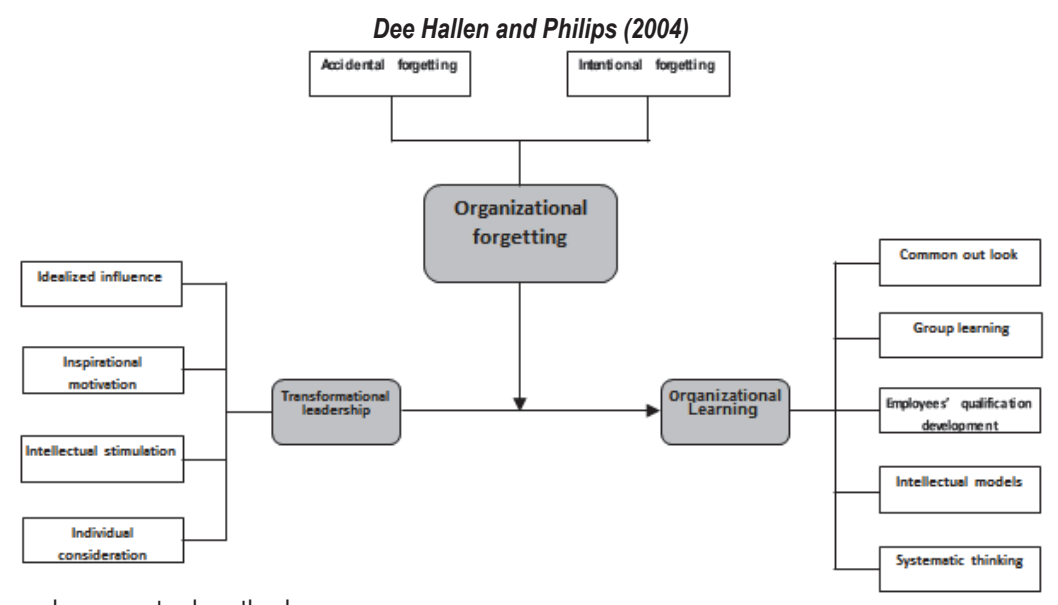

Figure 1: Research conceptual method

According to what has be mentioned, this research is going to examine how transformational leadership influences the organizational learning. In the research model, transformational leadership method of Bas and Olive (2000) is independent variable and organizational learning of Senge (1990) is dependent variable. Here, according to the role that organization-learning variable of Dee Hallen and Philips have in the level of leadership method impact on learning, it is selected as the moderator variable. Following figure shows the research intellectual model.

\section{Research methodology}

Research methodology is mentioned according to two index of research goal and data collection method. Therefore, following research is practical in terms of nature and goals and is descriptive and correlation in terms of data collection method. Also in terms of the variable control is non-pilot and in terms of time is sectional and its main strategy is surveying because the research is done at one point in time.

\subsection{Subject, spatial and time domain}

Subject domain: this research is about human resource management and organizational behavior management.

Spatial domain: this research is done in Astara custom organization.

Time domain: it is done in the year 2015. Data collection process which involves data collection, pre-exam, main exam, distribution of questionnaire and interpretation of results, was began in Azar of year 1394 (December 2015 and finished in Esfand of year 1394 (March 2016). 


\subsection{The tools and methods of data collection}

Data collection tools in this research is the questionnaire. It should be noted that in order to complete the data collection process, group and individual interview has been used. In following research, the rating scale was used for ranking data that ask responsive to write the amount of agreement or disagreement for any item based on spectral five-item of Likert.

\subsection{The statistical population and sample size and sampling method.}

The population of research according to research variable level that is in the organization and organizational units, population is 138 employees of Astara custom organization. Therefore, the questionnaires were distributed to 110 people and after getting questionnaires of 103 people, collection of the other questionnaires stopped. The sampling size is calculated through Kokoran formula in limited society by available sampling method.

\subsection{Validity and stability of questionnaire}

\subsubsection{Validity}

Validity means true and correct. The goal of validity is to the measurement tool could measure the intended feature. The importance of validity is to any inappropriate and inadequate measurement cause the research become worthless and unusable.

A. Kmo test: One of the methods that the research could recognize the appropriate data for factor analysis is Kmo test. The amount of statistic in this test changes frequently between 0 and 1 . If the statistic be fewer than 0/5, data are not inappropriate for factor analysis and if it is between 0/5 to 0/69 we could do factor analysis with more and finally if it is more than 0/7 we can say that correlations between data are appropriate for factor analysis.

B. Bartlett test: The other method to recognition of appropriate data is the Bartlett test. It tests the hypothesis that the observed correlation matrix belongs to society with uncorrelated variables. To be a useful and significant factor model it is necessary variables be correlated.

\begin{tabular}{|l|l|c|c|c|}
\hline VARIABLE & COMPONENTS & KMO & THE RESALTS OF EXPLAIND VARIANCE & RESULT \\
\hline \multirow{4}{*}{ Transformational leadership } & Intellectual stimulation & $0 / 807$ & $63 / 972$ & Confirmed \\
\cline { 2 - 5 } & Idealized influence & $0 / 776$ & $53 / 912$ & Confirmed \\
\cline { 2 - 5 } & Inspirational motivation & $0 / 832$ & $62 / 380$ & Confirmed \\
\cline { 2 - 5 } & Individual consideration & $0 / 819$ & $64 / 306$ & Confirmed \\
\hline \multirow{5}{*}{ Organizational learning } & Qualification development & $0 / 788$ & $65 / 662$ & Confirmed \\
\cline { 2 - 5 } & Intellectual models & $0 / 872$ & $68 / 662$ & Confirmed \\
\cline { 2 - 5 } & Common outlook & $0 / 832$ & $75 / 587$ & Confirmed \\
\cline { 2 - 5 } & Group learning & $0 / 832$ & $87 / 224$ & Confirmed \\
\cline { 2 - 5 } & Systematic thinking & $0 / 853$ & $87 / 661$ & Confirmed \\
\hline \multirow{2}{*}{ Organizational forgetting } & Intentional & $0 / 951$ & $71 / 121$ & Confirmed \\
\cline { 2 - 5 } & Accidental & $0 / 793$ & $40 / 325$ & \\
\hline
\end{tabular}

\subsubsection{Reliability}

During this research, the designed questionnaires completed by under studying sampled people and then variables Cronbach's alpha calculated by Spss software. As shown in the table 1, since the resulting combination final factor for each variables and questionnaire is more than 0.7 , consequently, we could say that following questionnaire has good reliability. 
Table 4: Reliability of questionnaire

\begin{tabular}{|c|l|c|c|}
\hline Row & Components & Numbers of questions & Cronbach's alpha \\
\hline 1 & Transformational leadership & 20 & $76 \%$ \\
\hline 2 & Intellectual stimulation & 5 & $79 \%$ \\
\hline 3 & Idealized influence & 5 & $81 \%$ \\
\hline 4 & Inspirational motivation & 5 & $84 \%$ \\
\hline 5 & Individual consideration & 5 & $88 \%$ \\
\hline 6 & Organizational learning & 24 & $78 \%$ \\
\hline 7 & Employees' qualification development & 6 & $75 \%$ \\
\hline 8 & Intellectual models & 6 & $88 \%$ \\
\hline 9 & Common outlook & 4 & $82 \%$ \\
\hline 10 & Group learning & 4 & $90 \%$ \\
\hline 11 & Systematic thinking & 4 & $85 \%$ \\
\hline 12 & Organizational forgetting & 20 & $89 \%$ \\
\hline 13 & Intentional organizational forgetting & 10 & $75 \%$ \\
\hline 14 & Accidental organizational forgetting & 10 & $79 \%$ \\
\hline
\end{tabular}

\section{Data Analyzing}

In following research, descriptive statistics and inferential statistical techniques will be use to analyze data. Some information about demographic characteristics of respondents are collected and presented through descriptive statistics. Then, the distribution of variables of research is analyzed according to the most important central index (mean and median), diffusion index (variance and and deviation) and index of distribution (Skewness and Kurtosis).

\subsection{Descriptive statistics}

\subsubsection{Demographic characteristics of the sample}

\subsubsection{Gender}

In this part, demographic characteristics of the sample are defined as follow.

Table 2: The frequency distribution of respondents in terms of gender.

\begin{tabular}{lccc}
\hline Studied variable & Gender & Frequency & Frequency percent \\
\hline Gender group & Female & 30 & $28 \%$ \\
\hline & Male & 73 & $72 \%$ \\
\hline & Total & 103 & $100 \%$
\end{tabular}

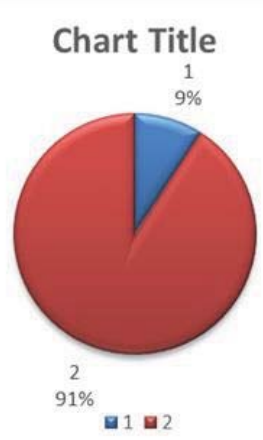

Figure 1: The status of respondents in terms of gender 


\subsubsection{Age}

Table 3: The frequency distribution of respondents in terms of age

\begin{tabular}{cccc}
\hline Studied variable & groups & number of repetitions & frequency present \\
\hline \multirow{3}{*}{ Age classes } & 20 to 30 & 18 & $17 / 25 \%$ \\
\hline & 30 to 40 & 12 & $10 / 75 \%$ \\
& 40 to 50 & 60 & $58 / 5 \%$ \\
\cline { 2 - 4 } & So to 60 & 13 & $12 / 25 \%$ \\
\hline & Total & 103 & $100 \%$ \\
\hline
\end{tabular}

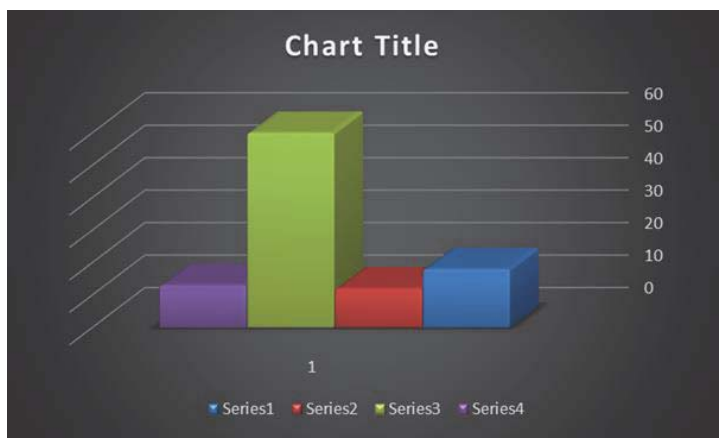

Figure 2: The status of respondents in terms of age

\subsubsection{Garde}

Table 4: The frequency distribution of respondents in terms of grade
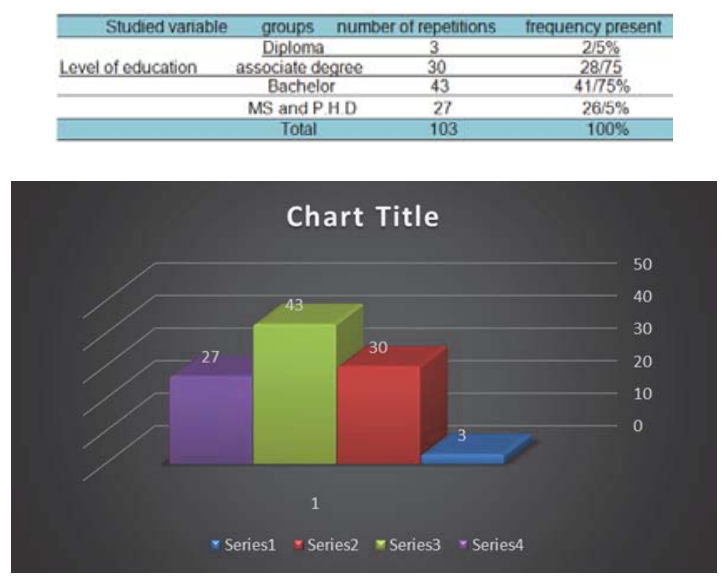

Figure 3: The status of respondents in terms of grade

\subsection{Inferential statistics}

To test the hypothesis, an appropriate test like T-test is used according to Kolmogorov-Smirnov test. Eventually, to review the same priority of indexes and factors, Freedman test is used. In addition, SPSS application is used in following research. 


\subsubsection{Analyzing the normality of variables}

The test to get needed permission to use regression and Pierson correlation coefficient apply on dependent and independent variables in order to normality of the information to be shown according to following hypothesis normality of data is analyzed:

$\mathrm{HO}$ : the data are normality distributed.

H1: the data are not normally distributed.

According to Kolmogorov-Smirnov test table, if any significant level for the all dependent and independent variables are more than test level (0/05), data distribution is normal.

Table 8: Kolmogorov-Smirnov test results of research variables

\begin{tabular}{|l|c|c|c|c|c|c|c|c|}
\hline & Number & Mean & Standard deviation & Absolute & Positive & Negative & $\begin{array}{c}\text { Kolmogorov- } \\
\text { Smirnov test }\end{array}$ & $\begin{array}{c}\text { Significant } \\
\text { level }\end{array}$ \\
\hline Transformational leadership & 103 & 2.5709 & 0.95974 & 0.226 & 0.226 & -0.226 & 2.228 & 0.067 \\
\hline Organizational learning & 103 & 2.5710 & 0.96058 & 0.225 & 0.225 & -0.225 & 2.226 & 0.068 \\
\hline Qualification development & 103 & 2.7803 & 0.75557 & 0.115 & 0.115 & -0.115 & 1.13 & 0.155 \\
\hline Intellectual model & 103 & 2.2705 & 0.95775 & 0.178 & 0.178 & -0.178 & 1.755 & 0.064 \\
\hline Outlook & 103 & 2.5887 & 0.96773 & 0.194 & 0.194 & -0.194 & 1.907 & 0.071 \\
\hline Group learning & 103 & 2.6072 & 0.10988 & 0.207 & 0.207 & -0.207 & 2.037 & 0.073 \\
\hline Systematic Thinking & 103 & 2.6079 & 0.21456 & 0.217 & 0.217 & -0.217 & 2.141 & 0.12 \\
\hline Organizational forgetting & 103 & 2.8262 & 0.81985 & 0.244 & 0.244 & -0.146 & 2.399 & 0.089 \\
\hline
\end{tabular}

As it is clear from table data, the significant level of Smirnov test for all research variables is more than (0/05). So all analyzed variables are normally distributed in following research questions.

\subsubsection{Pierson correlation test}

Before analyzing the model by regression, we should analyze the correlations between model variables. As shown in the table, correlation and significant numbers for variables are listed in pairs.

Table 9: Correlation relationships between dependent and independent variables

\begin{tabular}{|l|l|c|c|c|}
\hline & & Transformational leadership & Organizational learning & Organizational forgetting \\
\hline \multirow{2}{*}{ Transformational leadership } & Pierson correlation & 1 & & \\
\cline { 2 - 5 } & Significant level & & & \\
\hline \multirow{2}{*}{ Organizational learning } & Pierson correlation & ${ }^{\star \star} 0.738$ & 1 & \\
\cline { 2 - 5 } & Significant level & 0.000 & & \\
\hline \multirow{2}{*}{ Organizational forgetting } & Pierson correlation & ${ }^{\star \star} 0.969$ & ${ }^{\star \star} 0.718$ & 1 \\
\cline { 2 - 5 } & Significant level & 0.000 & 0.000 & \\
\hline
\end{tabular}

\section{Research results and suggestions}

The results shows that the seen statistics is fewer than working square statistics. Therefore, accidental organizational learning do not moderate the transformational leadership and organizational learning. In addition, the moderating effect of the intentional organizational learning (not accidental) are approved on the relationships between transformational leadership and organizational learning. Hypothesis result summary are presented in the following: 
Table 10: Results summary of variables relationships

\begin{tabular}{|c|l|c|c|c|c|c|}
\hline Row & Hypothesis & $\begin{array}{c}\text { Significant } \\
\text { level }\end{array}$ & $\begin{array}{c}\text { Moderated } \\
\text { determine } \\
\text { coefficient }\end{array}$ & $\begin{array}{c}\text { Changing } \\
\text { coefficient }\end{array}$ & $\begin{array}{c}\text { Standard } \\
\text { determine } \\
\text { coefficient }\end{array}$ & R/C \\
\hline $\mathbf{1}$ & $\begin{array}{l}\text { Transformational leadership method } \\
\text { influences organizational learning }\end{array}$ & $0 / 000$ & $0 / 540$ & $0 / 375$ & $0 / 738$ & Confirmed \\
\hline $\mathbf{2}$ & $\begin{array}{l}\text { Transformational leadership method } \\
\text { influences employees qualification } \\
\text { development }\end{array}$ & $0 / 000$ & $0 / 826$ & $0 / 716$ & $0 / 910$ & Confirmed \\
\hline $\mathbf{3}$ & $\begin{array}{l}\text { Transformational leadership method } \\
\text { influences intellectual models }\end{array}$ & $0 / 000$ & $0 / 936$ & $0 / 966$ & $0 / 96$ & Confirmed \\
\hline $\mathbf{4}$ & $\begin{array}{l}\text { Transformational leadership method } \\
\text { influences common outlook }\end{array}$ & $0 / 000$ & $0 / 928$ & $0 / 972$ & $0 / 964$ & Confirmed \\
\hline $\mathbf{5}$ & $\begin{array}{l}\text { Transformational leadership method } \\
\text { influences group learning }\end{array}$ & $0 / 000$ & $0 / 941$ & $1 / 22$ & $0 / 970$ & Confirmed \\
\hline $\mathbf{6}$ & $\begin{array}{l}\text { Transformational leadership method } \\
\text { influences systematic thinking }\end{array}$ & $0 / 000$ & $0 / 942$ & $1 / 229$ & $0 / 971$ & Confirmed \\
\hline
\end{tabular}

Table 11: Continuation of results summary of variables relationship

\begin{tabular}{|c|l|c|c|c|}
\hline Column & hypothesis & $\begin{array}{c}\text { effect of moderating variable: } \\
\text { statistics amount U0 }\end{array}$ & $\begin{array}{c}\text { compared with working } \\
\text { square statistics }\end{array}$ & R/C \\
\hline 7 & $\begin{array}{l}\text { Organizational learning moderates the effect of transformational } \\
\text { leadership method on organizational learning }\end{array}$ & $8 / 7$ & $3 / 84<8 / 721$ & $\mathrm{C}$ \\
\hline 8 & $\begin{array}{l}\text { Intentional organizational learning moderates the effect of } \\
\text { transformational leadership method on organizational learning }\end{array}$ & $36 / 860$ & $3 / 84<36 / 860$ & $\mathrm{C}$ \\
\hline 9 & $\begin{array}{l}\text { Accidental organizational forgetting moderates the effect of } \\
\text { transformational leadership method on organizational learning. }\end{array}$ & $3 / 535$ & $3 / 84>3 / 535$ & $\mathrm{R}$ \\
\hline
\end{tabular}

\subsection{Practical suggestions}

1. As we said organizations are learned by people. Ofcourse peoples learning do not guaranty the organizational learning. Nevertheless, organizational learning do not done without it. Argeris and Sechon declared that individual learning is necessary but is not enough for organizational learning. In addition, the individual learning is necessary to continuous development of organization and development of core capabilities and preparation everyone to uncertain future. The commitment of everyone to learning and his learning ability is necessary for organization. According to these contents, to improve the organizational learning the individuals should learn as a member of the organization and transfer it in organization. In other words, share the learned knowledge. Therefore, the individual's learning methods who could be used are: Books and others documents, coaching the others, periods, classes and seminars, interpreting experience and learning from it, self learning, learning from partners and learning through computer and etc.

2. According to the research results, although transformational leadership method influence organizational learning but the learning dimensions average shows that in curriculums there is more concentration on employees learning amount. It is suggested to use set up which is for learning improvement and its dimension include educational periods for employees and formation of committees and working groups. Also development and improvement of employee participation be considered in ideas and innovation and setting goals.

3. Since the organizational learning associated with organizational forgetting, solutions considered in order to remove non-functional and outdated knowledge. In other words, planners pay more attention to the action plans and operating procedures of intentional organizational forgetting as made more preparation to increase the old knowledge forgetting to speed up the learning process.

4. One of the actions that organizational leaders should support it and try hard to present a mechanism to operate out it among the managers, is organizational forgetting. For this purpose, organizational leaders should present the landscape image of future to senior managers and ask the managers of each part to manage knowledge and intentional forgetting and its needed mechanism. 
5. It is suggested to following items be in agenda: strategic planning, remote conference, modeled, sessions, learning by doing, social applications, practical workshop, parallel learning structures, create multitasking teams.

6. In order to increase the organizational learning, except the creating knowledge in organization, manager should also has more attention to the knowledge out of organization. Transformational leaders should provide the model fields in the organization. Therefore, we should use conventional strategies of this field efficiently.

7. As it is obvious from research theoretical literature, organizational learning achieved through sharing the vision, knowledge, experience and intellectual models of organization members. Organizational learning also be established based on knowledge and experience that exist in organizations memory and it is relies on mechanism such politics, strategies and models on knowledge store. Organization leader as the main decision maker and the main conductor of organization should facilitate the strengthening the learning loop, order to execute appropriate strategy, identify and store knowledge and share the knowledge.

8. Group learning is the entrance of organizational learning. Leaders should be role producer and conductor of group work culture in organizations and they are responsible of one of the group work supporters in organization. If group works are created and supported, group learning, it will cause convert the learning to organizational knowledge so that it is shared to all.

9. Organizational leaders should motivate the employees to personal development that is one of the important ways to organizational and individual learning, which guaranty the interests of organization and individual future career. Some of the important strategies of individual learning which transformational leaders increase the group and individual learning by them, are as follows: Personal development, Managers as a teacher, Job transition, Coaching, Special tasks.

\subsection{Suggestions for the further researches}

1. In further researches, we can research about the fields of effective factors on organizational learning and the relationship between the other leadership methods and organizational learning and do comparative study with following research results. In addition, one of the factors in this research that is paid less attention and can be studied again is environmental condition necessities for organizational learning which can be a new suggestion for the next researches itself.

2. The next researches also need to more sample studying. We can study more organizations from the geographical pin of view, identify, study, and compare these factors between various organizations. In addition, researches about how to use and influence of each of these factors in organizations can be useful. It is suggested that the next studies done in following fields:

- Comparative study of influence of leadership method on organizational learning.

- Influence of inside and outside organization factors on organizational learning.

- Presentation of organizational forgetting process according to organizational condition and organizational learning needs to create competitive advantage.

- Identify strategies to improve organizational learning in order to increase competitiveness and organizational innovation.

3. Since the organizational forgetting is important and it is done few researches especially about the amount of forgetting in governmental and personal organizations, it is suggested that this comparison be done and its results presented.

4. Finding some solutions to decrease the amount of accidental organizational forgetting could be the research topic so that organizations through using its results can do actions in order to replace the new practical knowledge with old knowledge.

5. It is suggested that the influence of intentional organizational forgetting on improvement of organizational operation be studied and also doing qualitative researches about the main factors of intentional organizational forgetting research in Iran or qualitative researches about identifying accidental forgetting factors could be the topic of next researches.

\subsection{Research barriers}

Any research is faced some barriers. Besides, the problems that the researcher faced them during the research like: lack of knowledge about research topic, the distance and etc., this research also faced some barriers: Research results may 
lose its environmental capabilities due to changing position in the long term but following research now has the extension capability at least in short term and we can make decision according to it.

It should be noted that following research is sectional and we could not expect an excellent relationship, which exist in experimental and continuous researches.

The data collection tools in this research is questionnaire and the questionnaire has inherent limitations itself.

The following research has done in Astara. To generalizability of this research results to other companies or similar companies and population in other geographical areas should be cautious.

\section{References}

Argris, C.; Schon, D. A. (1977).Organizational learning: A theory of action perspective. New York: Addison Wesley.

Avolio, B. J., Zhu, W. Koh, W., and Bhatia, P., 2005. Transformational leadership and organizational commitment: mediating role of psychological empowerment and moderating role of structural distance. Journal of Organizational Behavior, 25, pp. 951-68.

Azmi, F. T. (2008). Mapping the Learn-Unlearn-Relearn Model Imperatives for Strategic Management. Indian journal of training \& development, pp. 4-14.

Bass, Bernard M, Avolio, Bruce J, Jung I, Dong. Berson, Yair(1990). Predicting Unit Performance by Assessing Transformational and Transactional Leadership.Journal of Applied Psychology.88 (2), 207-218.

Bennis, W. G., and Nanus, B. (1985). "Leaders: the strategies for taking charge", New York: Harper \& Row.

Besanko D. , Doraszelski U. , Kryukov Y. and Satterthwaite M. (2007). Learning-by-doing, organizational forgetting and industry dynamics.

Boenke.k, B .N, Distefano.j.j, and Distefano.A.C. (2003). "Transformational leadership", Leadership and Organizational journal, Vol.1, No.24, p.5-6.

Burke, S., and Collins, K.M. (2001). "Gender differences in leadership styles and management skills", Women in Management Review, Vol. 16, No.5.pp 244-256.

Chuch C. H. law, Eric W.T. Ngai,(2008), "An empiricul study of the effects of knowledge sharing and learning behaviors on firm performance", Elsevier, Expert systems with applications.

De Holan P.M, Phillips, N and Lawrence T.B. Managing organizational forgetting. MIT Sloan Management Review 2004; 45(2): 44-51.

Fernandez, V. \& Sune, A. (2009). Organizational Forgetting and its causes: anempirical research. Journal of Organizational Change Managemt, Vol. 22, No. 6, pp. 620-634, ISSN 0953-4814.

Azar, Adel. Momeni, M. and Fakher, Islam (1391). Solving the problems of Statistics and Its Application in Management (statistical analysis). Tehran, SEMAT publication, pp. 114-116.

Stacey, Ralph, (1389), Strategic thinking and change management (international perspective on organizational dynamics), translation by Mostafa Ja'fari and Mahzyar Kazemi, third edition, Tehran: Rasa publication.

Akhavan peyman. Jafari, M., (1385). Investigation the relationship between transformational leadership or organizational learning (Case Study: Saipa). Research a change management (a management study). Volume 3, Issue 6.

Amir, AR; Khodayari, Abraham, comments, F., Moradi, M., (1385). The relationship between transformational and transactional leadership styles and organizational commitment, management, organizational culture, Issue 1.

Amir Kabiri, kasraie, AR. (1393). The effect of transformational leadership, innovation and organizational learning on performance of the State Tax Administration of north Tehran, Islamic Azad University - Central Tehran Branch, Islamic Azad University, Institute of Science and Technology in Iran.

Ansari, Mohammad Ismail and Teymouri, H. (1386). Director in the role of a transformational leader, Tadbir monthly journal, No. 189.

Burumand, Z. (1374). Management of Organizational Behavior. Tehran: Cultural Research, page: 50.

Pourjafari, Maryam. (1393). The impact of transformational leadership on employee empowerment mediation-oriented learning. Semnan University, Enterprise Resource Management Research, Vol. 5, No. 1, 1-18.

9tons Hu, Steven and others, (1386), key management models; translator, Ali Akbar cultural and Safarzadeh and Mehdi Khadem, first edition, Tehran: expressive.

Jalili, S. (1393). A Model for Effective organizational forgetting challenge for today's managers.

Choupani Heydar, Siadat Seyed Ali, Kazem pour Maryam, Rauf Rahimi, Hasanvand. Muslem (1392). Enhancement of learning in organizations in the light of the role of transformational leadership, Isfahan University of Medical Sciences in the academic year 1392-1391, Health Management - 1392 - Volume 16 - Issue: 52 - Page: 37 -50.

Hajii Aziz, Nadia. (1388). Organizational Forgetting: A New Approach in Knowledge Management, Journal of Iranian Research Institute for Information Science and Technology, Volume 25, Issue 2, 317-330.

Hafeznia, m., F., (1387), Introduction to Research Methods in Human Sciences, Tehran: Right, published 13.

Hafeznia, M., 1382, 1385, Introduction to Research Methods in Human Sciences, Tehran, publisher side.

Hosseini, Seyed yaghoub, (1392). Prioritizing the factors affecting organizational forgetting: Using the fuzzy network with non-linear programming approach, Issue IX. 13-20. 